\title{
Smart services - characteristics, challenges, opportunities and business models
}

\author{
Katrin MARQUARDT \\ The Bucharest University of Economic Studies, Bucharest, Romania \\ muellerka@hotmail.de
}

\begin{abstract}
Industry 4.0", "Digitalization", "Internet of Things" and "Smart Services" are the today's buzzwords when tracking economic news. It is to ask about the meaning of those phrases. The world has changed over the last decade from a mainly physical to software controlled economy and the information technology has become an integral part of our industry and society in its entirety. Nowadays it is no longer the product that matters it is the data that are generated by using the product or service. Those usage data collected and analyzed commence new business models and services. The economic future of a company will much more rely on the ability to collect and use the data to generate Smart Services for their customers and to transform from a simple product supplier to an entertainment provider. However there are not only opportunities there are also challenges on the way to that new services which needs to be known and considered. For instance the development cycles need to be faster, the business models need to be adjusted and the positive financial results will not come into the picture on the first day. Based on those thoughts and while there only a handful of researches about that new services exists, the main purpose of the present study is at first, to gain a common understanding about the meaning and the characteristics of Smart Services and their adjacencies. Secondly, the study summarizes the identified challenges and opportunities in relation to them. Thirdly, the author introduce and explain the main business models usable for those Smart Services and the requirements for starting the transformation towards those services. The aim of this paper is to set a basis for this exciting and relatively unsought topic and to produce an interest in further empirical and practical researches in this area. The methodologies used for this research are a systematic literature review and an evaluation of existing studies with the subjects "Industrie 4.0", "Digitization", "Internet of Things" and "Smart Services". Additional national initiated programs and best-practice of transformations where analyzed and interpreted. The outcome of the study is always focused on service providers.
\end{abstract}

Keywords: Smart Services, Industrie 4.0, Digitalization, Internet of Things, web, business model.

\section{Introduction}

The global economy has to face numberless challenges caused by demographic changes, declining availability of resources, globalization of the markets and growing international competition. Furthermore the ever-expanding customer and quality requirements and the associated demand for innovations require a reorientation and a higher flexibility of the companies to secure their future (Marquardt et al., 2017; KPMG, 2016; O'Halloran and Kvochko, 2015). Therefore it is no wonder that in the business news buzzwords like "Digitalization", "Internet of Things" (IoT), "Industrie 4.0", "Big data" and "Smart Services" are indispensable. With the help of Google Trends (Service based on Google Search that shows in real time how often a particular search-term is entered in relation to the total search-volume, it can be clustered by countries.), analysis it can be demonstrated how the interest in the population about those topics has grown as an example in Germany over the last three years. 


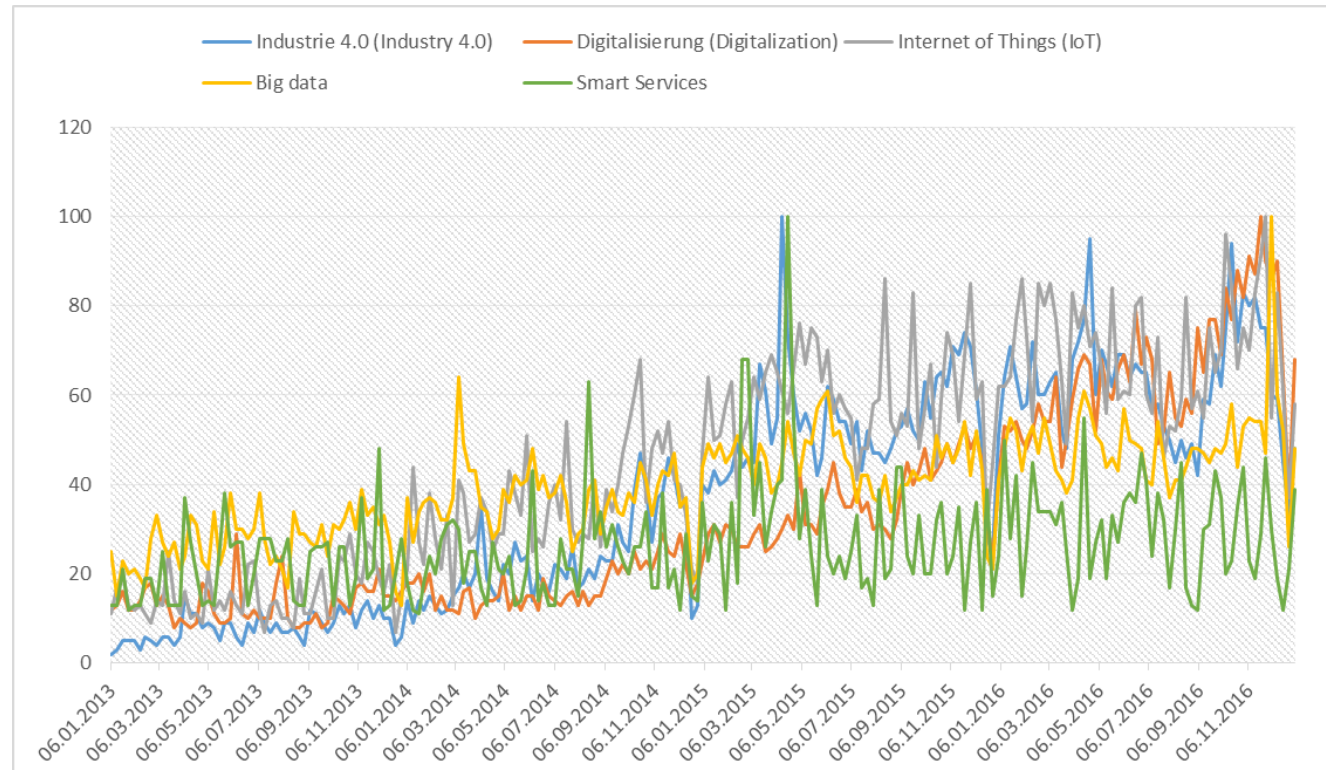

PICBE | 790

Figure 1. Google Trends - Web search all categories for the selected words within the last 3 years in Germany

Source: Author's design based on data from Google Trends, 2017.

Likewise a check of the citation reports on Thomson Reuters Web of Science (2017) shows that the publications to those topics have multiplied or partially doubled within the past years. However the so called fourth industrial revolution or digital change or industrial internet is disputed, in many publications and forums, you find ongoing discussion if it is a revolution or evolution or if it is just a hype (Syska and Liévre, 2016; O'Halloran and Kvochko, 2015; Wee et al., 2015; Brynjolfsson and Mcafee, 2014). In a nutshell it can be summarized: there are a lot of opportunities predicted, a vast amount of challenges to be managed and at the end for governments and companies it is about the command of the strategic important control points in the future value-creation-chain to defense potential competitors and to ensure their survival on the world market. To support this development several enterprise companies and governments have launched strategic programs and initiatives in the last years like the Industrial Internet Consortium (IIC) founded in America by global IT companies (iiconsortium.org, 2017) and the "Autonomics for Industrie 4.0" and "Smart Service World" programs initiated in Germany by the government (BMWi, 2016). The aim of those programs and initiatives is to establish a common understanding, provide guidance for the digital change, develop and define new standards and platforms to support the changes and never the less to set their claims.

In figure 2 the author has combined the main industrial evolution steps, the main developments of the web and the vision of the future. To make it more tangible some statistical data where added and major technical innovation in the direction of mobility. Comparing for example the number of internet users in the middle of the nineties of about 100 million with the number at 2010 with more than 2 billion and that at this time the world population was about 6.92 billion in total (UN DESA, 2017) give an impression of the astounding speed of the evolution and how vast the penetration of the internet has grown. 


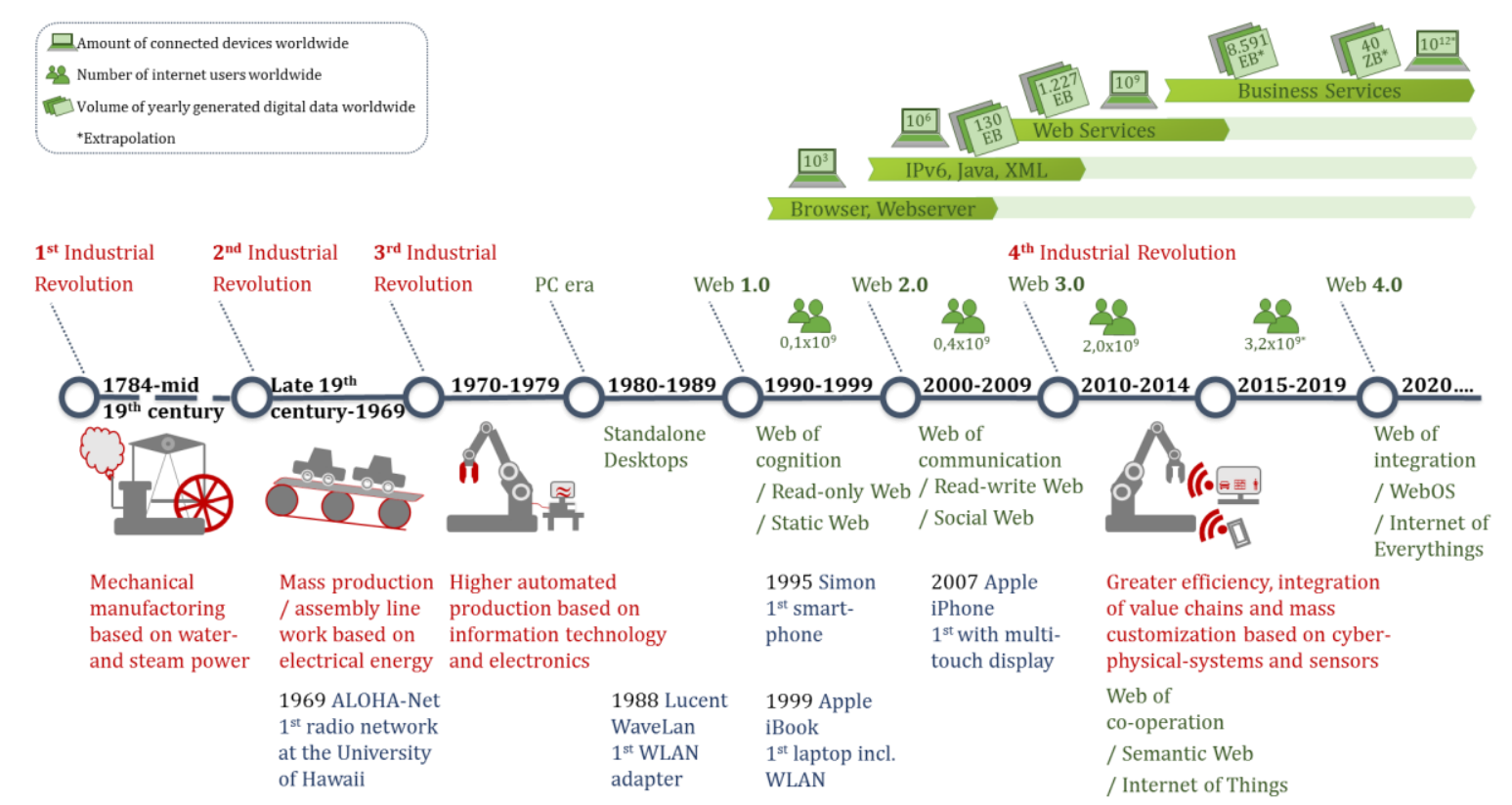

Figure 2. Main evolution steps of the industry and web (internet) incl. statistical data and vision of the future

Source: Author's design based on data from UN DESA, 2017; Davies, 2015; IDC, 2015; Tydecks, 2013; Aghaei et al.; 2012, Bosch SI, 2012).

The growing dependence on this ubiquitous technology and the increasing customer demands request new ways of thinking and acting to identify and deal with the new opportunities and be aware of the related challenges. As it was said by Louis Pasteur "Chances favors only the prepared mind" (Goodreads, n.d.). Outgoing from those thoughts it is indispensable to do further researches in the new emerging fields and there especially in the area of Smart Services, the nuggets of the near future and from the author's point of view the less explored and explained topic. The main aim of this research is therefore to uncover the meaning and characteristics of Smart Services, their implications on companies, customers and business models, as well as the determination of the preconditions for transforming towards those new services. The objective behind identifying these points is also to gain understanding of best practices related to Smart Services and to produce an interest in further empirical and practical researches in this area.

\section{Literature review}

\section{The methodology and the main terms}

A systematic literature review, examining articles and papers published in research journals, governmental publications, surveys and studies from well-known consulting and research companies and websites was conducted. The research was done online by using the following main search engines and databases: Emerald Management Journals, Scopus, Elsevier, Springer and Google Scholar. The focus was on publications from the last 5 years and with the subjects: "Industrie 4.0", "Digitization", "Internet of Things" and "Smart Services". Followed by a structured selection process based on subject relevance and data quality the used material was further narrowed down from about 180 publications to about 
65 relevant publications. This research has been realized between December 2016 and February 2017.

Hence the first point identified was the close correlation of Smart Services with digitalization and interconnectedness as well as big data and data analytics. As second it emerged that there only a handful of researches exist on Smart Services directly and the associated opportunities, challenges and proposed business models. As a starting point and to gain a common understanding, the main terms related to the research field are summarized and shortly explained in table 1.

Table 1. Short explanation of the main terms related to the research field

\begin{tabular}{|c|c|}
\hline Term & Meaning / Definition \\
\hline Industrie 4.0 & $\begin{array}{l}\text { - Industrie } 4.0 \text { was the } 1 \text { st time presented } 2011 \text { on the Cebit in Hannover as an } \\
\text { initiative out of economy, politics and science (Kagermann and Lukas, 2011). } \\
\text { Industrie } 4.0 \text { is one of } 10 \text { future projects of the German government's High- } \\
\text { Tech Strategy } 2020 \text { (BMBF, 2014). } \\
\text { Industrie } 4.0 \text { is often summarized as the connection of the virtual with the } \\
\text { physical world, and depends on the following main innovative technological } \\
\text { developments: } \\
\text { Information and communication technology (ICT), to digitize information } \\
\text { and integrate systems } \\
\text { Cyber-physical systems, involve embedded sensors, intelligent robots, } \\
\text { additive manufacturing } \\
\text { Network communications including wireless and internet technologies } \\
\text { Simulation, modelling and virtualization in product design and process } \\
\text { establishment } \\
\text { Big data analysis and cloud computing } \\
\text { Robotics, augmented reality and intelligent tools to support human } \\
\text { workers (Davies, 2015). }\end{array}$ \\
\hline Digitalization & $\begin{array}{l}\text { "Digitalization is the use of digital technologies to change a business model } \\
\text { and provide new revenue and value-producing opportunities; it is the process } \\
\text { of moving to a digital business" (Gartner, n.d.). }\end{array}$ \\
\hline Web 3.0 & $\begin{array}{l}\text {-Web } 3.0 \text { is the next fundamental change both in how websites are created } \\
\text { and more importantly, how people interact with them."(Nations, 2016) } \\
\text { Web } 3.0 \text { is often on a par with semantic web which means that the content of } \\
\text { webpages will enhanced with machine-readable annotations (Schibrowski, } \\
\text { 2008). }\end{array}$ \\
\hline $\begin{array}{l}\text { Internet of } \\
\text { Things }\end{array}$ & $\begin{array}{l}\text { - The Internet of Things (IoT) is simply the connection from on and off } \\
\text { switchable devices to the internet. They get a virtual presence and can } \\
\text { connect to other objects and database data (Morgan, 2016). }\end{array}$ \\
\hline $\begin{array}{l}\text { Internet of } \\
\text { Services }\end{array}$ & $\begin{array}{l}\text { - The Internet of Services (IoS) enables a simpler and faster creation and } \\
\text { configuration of new, web-enabled services and to offer them on the Internet } \\
\text { based on development- and service platforms (Wahlster, 2008). }\end{array}$ \\
\hline Smart product & $\begin{array}{l}\text { - Products with embedded IT technology that collect, process, produce and } \\
\text { transmit usage data are named smart or intelligent products (Cronin, 2010; } \\
\text { Rijsdijk and Hultink, 2009). } \\
\text { - Those smart products will be able to : } \\
\circ \quad \text { Perform independent tasks and do self-updating } \\
\text { O Adapt themselves to the needs of the customer } \\
\text { Identify failures and act proactively towards them } \\
\text { - Continuously reduce their running costs, optimize them-selves and } \\
\text { increase their productivity } \\
\text { - Communicate with other things (Steimel, 2016) }\end{array}$ \\
\hline
\end{tabular}




\begin{tabular}{ll}
\hline Big data & $\begin{array}{l}\text { Big data is used as a synonym for vast and complex data volumes which } \\
\text { differs by their size, diversity and rapid pace of change and that can be } \\
\text { processed only limited by current databases and data management tools } \\
\text { (Plattner, 2016). }\end{array}$ \\
Smart data & $\begin{array}{l}\text { Smart data can be defined as the useful extract of Big data. At this juncture } \\
\text { the unstructured data are processed, analyzed, interpreted and reassembled } \\
\text { with the help of information extraction methods and machine learning } \\
\text { (Kagermann et al., 2015). }\end{array}$ \\
Business & $\begin{array}{l}\text { It is the answer to three simple questions: } \\
\text { model }\end{array}$ \\
& $\circ \quad$ How the company want to earn money and fulfill the customer \\
& requirements? \\
& $\circ \quad$ How the company can grow its business? \\
& achieve company survive the competition on the market and can \\
&
\end{tabular}

PICBE | 793

At this point it should be noted that a uniform definition does not exist for all the terms. The more the development progresses and researches carried out in these areas, the more precisely the individual terms can be separated from each other and standard definition will emerge.

\section{Smart Services and their characteristics}

Nowadays a lot of products and services have names starting with "smart", for example smart phone, smart TV, smart home, smart energy and so on. But what does the word "smart" mean, what is the message behind? Simple synonyms for "smart" are: clever, patent, skilled, stylish and efficient and those should basically be the qualities of products and services which contain this word. It is difficult to figure out where "smart" appeared in product names for the first time, but it can be seen as a trend over the past few years. Soon it was not enough to offer a product or a service, it had to be a "smart" one that's why it was no wonder that Smart Products and Smart Services came up as the new things to be developed and provided.

In the reviewed studies and publications single definitions for the term "Smart Services" were identified explaining their strong dependence on the type of business (e.g. manufacturing, suppliers and service providers) or on the contexts (e.g. smart factory, internet of things, Big data and digitalization) they are associated with. To give a résumé the author selected the following five characteristics to define Smart Services:

- Connection between the physical and the digital world;

- Upgrade of value creation and economic efficiency;

- Extension of products and services with a digital level;

- Transformation of the product into a part of service;

- Change from product centred to customer centred business models (Steimel, 2016; eurodata, 2015; Allmendinger and Lombreglia, 2005).

Further differentiators identified towards classical services are their strong dependence on data; the required high agility during the development and that Smart Services will be often produced cross-company and cross-sectoral (Kagermann et al., 2015).

The Smart Urban Services project defined "Smart Services" as services tailored to specific customer used cases with the help of data and intelligent processing (Hermann, 2016). That's why for the design and development of Smart Services it is essential to understand the customer and his surroundings, to have smart data and platforms to 
integrate and process the data and to change the business models and company mind set. In the figure 3 the major prerequisites for establishing and providing Smart Services are combined and illustrated.

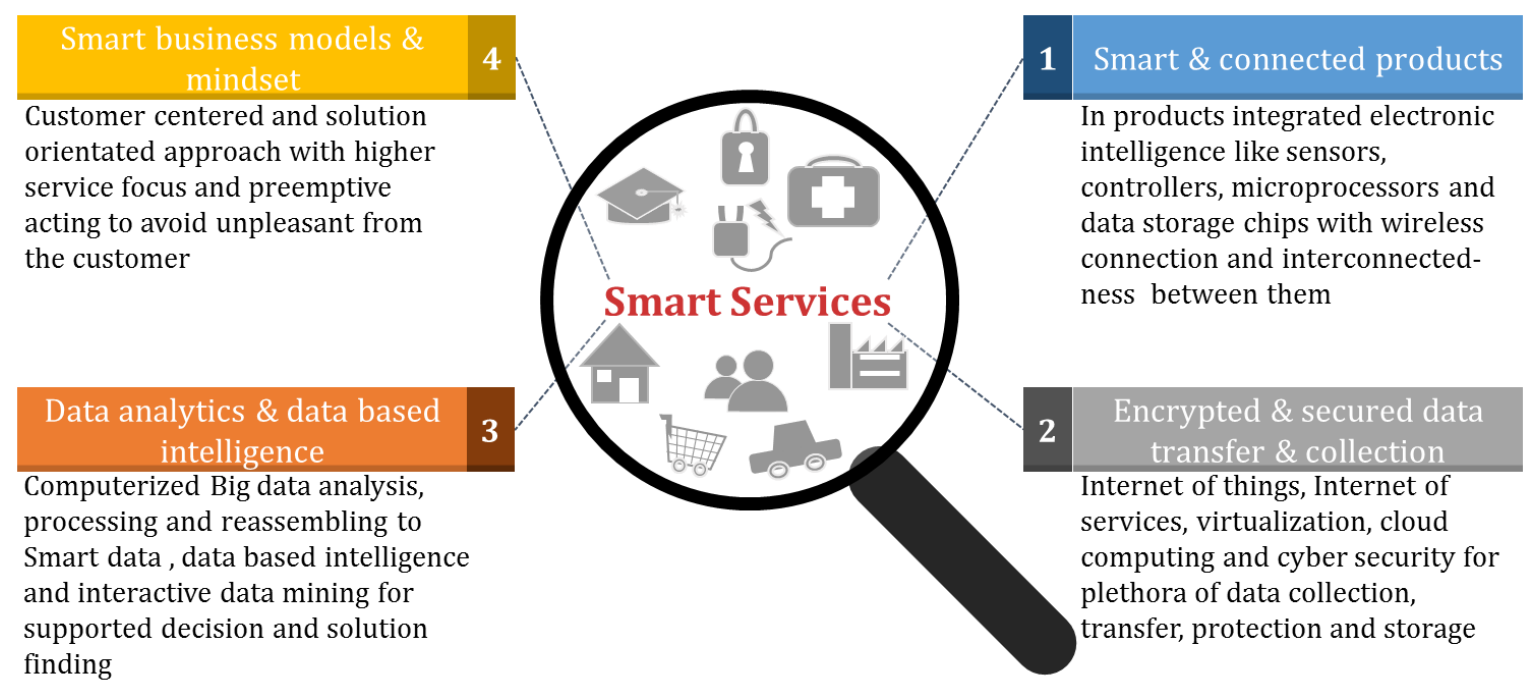

Figure 3. Main prerequisites for establishing and providing Smart Services

Source: Author's design.

\section{The challenges and opportunities}

From the author's perspective the today's main challenges for companies on the competitive market are: agility, progressiveness, to be visionary and on top of the evolution. It is needed to identify new opportunities for retain and to extend the business and to uncover fast potential challenges that are associated with the competition on the market. In case of Smart Services, the Big data, the intelligent platforms and their management are often mentioned as the future competitive advantage. In the same breath security and data privacy comes up driven by the growing network and vast amount of data collected and shared. Notable barriers like missing smart talents, missing standards and governance rules, new and vulnerable technologies and high investments with uncertain return on investments (ROI) are also listed in a lot of publications to that topic.

In the last two years named consulting and research companies like McKinsey, KPMG, Ernst and Young, PWC and the World Economic Forum conducted industrial surveys and studies in relation to the Industrie 4.0, Industrial Internet, Digitalization and Smart Services. As the main challenges and obstacles to be handled and overcome the following points (table 2) were synthesized out of the feedbacks presented in those studies. Sure that on the first view they seen not looking directly linked to Smart Services but nevertheless they are associated to the requirements that needs to be fulfilled to have the ability to provide Smart Services as pointed out in the table.

Table 2. Challenges related to Smart Services

\begin{tabular}{ll}
\hline Challenges & Associated prerequisites \\
\hline Lack of standards and interoperability & Intelligent platforms for data collection \\
\hline Data ownership, security and privacy concerns & Big data, Smart data \\
\hline High investments and uncertain ROI & IT infrastructure \\
\hline Deficits in technology and data analytics & Sensors and business intelligence to collect and \\
\hline
\end{tabular}




\begin{tabular}{|c|c|}
\hline & process data \\
\hline Scarcity of skilled workers and knowledge & Data analysts, data mining skills \\
\hline $\begin{array}{l}\text { Shortage of courage to change and } \\
\text { management }\end{array}$ & Visionary leadership, disruptive approaches \\
\hline Missing visions and business models & Identification of potentials, selling strategies \\
\hline
\end{tabular}

On the other side of the medal there are undoubtedly also opportunities. Talking about Smart Services and the new technology phrases like "new value creation" and "new kind of service" are coming up as the first realized business opportunities. But there is a lot more to envision, Smart Services will change a whole slew of domains in private and business economy and each parts. The discovered opportunities which can be associated directly or indirectly to Smart Services are described in table 3 and complemented with their cause and some examples.

Table 3. Opportunities related to Smart Services including their causes and examples

\begin{tabular}{|c|c|c|}
\hline Opportunities & Caused by & Examples \\
\hline $\begin{array}{l}\text { Additional } \\
\text { revenue }\end{array}$ & $\begin{array}{l}\text { Selling Smart Service as extensions to } \\
\text { existing products or services or as new } \\
\text { services }\end{array}$ & $\begin{array}{l}\text { - } \quad \text { Smartphone and apps } \\
\text { - Smart TV }\end{array}$ \\
\hline $\begin{array}{l}\text { Improved } \\
\text { efficiency }\end{array}$ & $\begin{array}{l}\text { Utilization of Smart Service like } \\
\text { monitoring, early alerting, predictive } \\
\text { maintenance and remote management }\end{array}$ & $\begin{array}{l}\text { - Toner fill level alerting } \\
\text { - } \quad \text { Proactive maintenance } \\
\text { based on usage data }\end{array}$ \\
\hline $\begin{array}{l}\text { Increased visibility } \\
\& \text { cost reduction }\end{array}$ & $\begin{array}{l}\text { Recovery and usage of the data collected } \\
\text { from Smart products and services and } \\
\text { resulting process optimization }\end{array}$ & $\begin{array}{l}\text { - } \quad \text { Smart home } \\
\text { - }\end{array}$ \\
\hline $\begin{array}{l}\text { Enhance customer } \\
\text { base, relationship } \\
\text { \& satisfaction }\end{array}$ & $\begin{array}{l}\text { Shift to outcome economy by delivering } \\
\text { what the customer needs or what helps } \\
\text { to fulfil his requirement and customer } \\
\text { centered business models }\end{array}$ & $\begin{array}{l}\text { - } \quad \text { As a service solutions } \\
\text { - } \quad \text { Care sharing } \\
\text { - } \quad \text { Food ordering }\end{array}$ \\
\hline $\begin{array}{l}\text { Larger mobility \& } \\
\text { independence }\end{array}$ & $\begin{array}{l}\text { Virtuality of the services which require } \\
\text { just a device with mobile connection }\end{array}$ & $\begin{array}{ll}\text { - } & \text { Navigation system } \\
\text { - } & \text { Online banking } \\
\text { - } & \text { Remote Health support }\end{array}$ \\
\hline $\begin{array}{l}\text { Stronger } \\
\text { interconnectedness }\end{array}$ & $\begin{array}{l}\text { Required data share around integration } \\
\text { platforms and cooperation along the } \\
\text { value chains }\end{array}$ & $\begin{array}{l}\text { - } \quad \text { Collaboration platforms } \\
\text { - Outsourcing }\end{array}$ \\
\hline $\begin{array}{l}\text { Faster decision } \\
\text { making and acting }\end{array}$ & $\begin{array}{l}\text { Use of data analysis, interactive data } \\
\text { mining and data based intelligence to } \\
\text { support humans }\end{array}$ & $\begin{array}{ll}\text { - } & \text { Virtual assistant } \\
\text { - } & \text { Autonomous driving }\end{array}$ \\
\hline $\begin{array}{l}\text { Higher employee } \\
\text { productivity, } \\
\text { satisfaction \& } \\
\text { qualification }\end{array}$ & $\begin{array}{l}\text { Automation of standard and reoccurring } \\
\text { tasks and higher work place flexibility } \\
\text { resulting in engaging work experiences }\end{array}$ & $\begin{array}{ll}\text { - } & \text { Chat robot } \\
\text { - } & \text { Mobile workplace } \\
\text { - } & \text { eLearning }\end{array}$ \\
\hline
\end{tabular}

Source: Author's aggregation based on Wee et al., 2016; Kagermann et al., 2015; Davies, 2015; O'Halloran and Kvochko, 2015; Steimel, 2015.

As a conclusion it can be stated, that Smart Services will effect education, health care, utilities, retail, manufacturing and transport significantly within the coming years and companies which do not face the challenges and metabolize the opportunities will inevitably get difficulties to survive on the market or cease to exist. As identified by Pekka Töytäri (2017) companies need awareness and connectivity to build up valuable Smart Services. 


\section{The business models and the requirements for transformation}

After exploring the characteristics, challenges and opportunities related to Smart Services it is fundamental to have a closer look to the so called "new business models" for Smart Services and what approaches are recommend to transform towards them. Most of the reviewed publications refer only to new business models and business model innovations but they do not name exactly which they are. Therefore it was necessary to widen the research and explore what are the most used business models in physical (traditional) and the digital (virtual) environment and to check their applicableness for Smart Services.

In table 4 the selected business models with a short description, physical and digital examples are listed. It is noted, that this table has no claim to completeness, it is just a compilation of the appropriate ones based on the author's viewpoint.

Table 4. Selected business models with applicableness for Smart Services

\begin{tabular}{|c|c|c|c|}
\hline Business Model & Description & Physical examples & Digital examples \\
\hline Subscription & $\begin{array}{l}\text { User must pay periodical (e.g. daily, } \\
\text { monthly, annually) fee to subscribe } \\
\text { to a product or service }\end{array}$ & $\begin{array}{l}\text { Newspapers, } \\
\text { magazines }\end{array}$ & $\begin{array}{l}\text { Netflix, Apple } \\
\text { Music }\end{array}$ \\
\hline $\begin{array}{l}\text { Utility or On- } \\
\text { Demand }\end{array}$ & $\begin{array}{l}\text { Payment is based on measured } \\
\text { usage or "pay as you go" approach } \\
\text { where the user pays only for what } \\
\text { he use for a specific time or volume }\end{array}$ & $\begin{array}{l}\text { Electricity, } \\
\text { prepaid card }\end{array}$ & $\begin{array}{l}\text { Uber, TaskRabbit, } \\
\text { Mobile Day pass }\end{array}$ \\
\hline $\begin{array}{l}\text { Advertising or } \\
\text { Free }\end{array}$ & $\begin{array}{l}\text { Is an extension of the traditional } \\
\text { media broadcast model, providing } \\
\text { free content or services and in } \\
\text { exchange display ads and collect } \\
\text { data for sell }\end{array}$ & TV, radio & $\begin{array}{l}\text { Pinterest, Google, } \\
\text { Facebook, Twitter, } \\
\text { Huffington Post }\end{array}$ \\
\hline $\begin{array}{l}\text { Community or } \\
\text { Social Media }\end{array}$ & $\begin{array}{l}\text { Similar to the model above by } \\
\text { offering a free online service or } \\
\text { space, requires user loyalty and is } \\
\text { financed via ads, subscription for } \\
\text { premium service }\end{array}$ & $\begin{array}{l}\text { Promotional events, } \\
\text { fairs }\end{array}$ & $\begin{array}{l}\text { RedHat, Wikipedia, } \\
\text { Facebook, LinkedIn }\end{array}$ \\
\hline Freemium & $\begin{array}{l}\text { The name is a combination of free } \\
\text { and premium and means that the } \\
\text { user get a basic service for free and } \\
\text { will be charged for premium } \\
\text { services }\end{array}$ & $\begin{array}{l}\text { Freeware, trial } \\
\text { licenses }\end{array}$ & $\begin{array}{l}\text { Spotify, LinkedIn, } \\
\text { Dropbox }\end{array}$ \\
\hline $\begin{array}{l}\text { Creator or } \\
\text { Manufacture } \\
\text { (direct) }\end{array}$ & $\begin{array}{l}\text { Design and produce products and } \\
\text { services and sell them }\end{array}$ & $\begin{array}{l}\text { Automotive } \\
\text { manufacturer }\end{array}$ & Dell, Microsoft \\
\hline $\begin{array}{l}\text { Distributor, } \\
\text { Reseller or } \\
\text { Merchant }\end{array}$ & $\begin{array}{l}\text { Buy and sell products and services } \\
\text { from others and sometimes add } \\
\text { value to it }\end{array}$ & $\begin{array}{l}\text { Car dealers, clothes } \\
\text { shops }\end{array}$ & $\begin{array}{l}\text { Amazon, Lands } \\
\text { End, iTunes } \\
\text { EMAG }\end{array}$ \\
\hline $\begin{array}{l}\text { Broker, Seller } \\
\text { or Marketplace }\end{array}$ & $\begin{array}{l}\text { Brings seller and buyer together by } \\
\text { providing a platform and gets } \\
\text { payed by transactions or } \\
\text { placement fees }\end{array}$ & $\begin{array}{l}\text { Auction house, } \\
\text { trading exchange }\end{array}$ & $\begin{array}{l}\text { eBay, AirBnB, Uber, } \\
\text { App Store, Trivago } \\
\text { OLX.ro }\end{array}$ \\
\hline $\begin{array}{l}\text { Owner, } \\
\text { Landlord or } \\
\text { Access-over } \\
\text { Ownership }\end{array}$ & $\begin{array}{l}\text { Sharing economy where someone } \\
\text { owns a product or service and } \\
\text { profits by charging temporary } \\
\text { with others }\end{array}$ & $\begin{array}{l}\text { Car rental, car } \\
\text { sharing }\end{array}$ & $\begin{array}{l}\text { AirBnB, Peerbuy, } \\
\text { Microsoft Azure } \\
\text { X as a Service } \\
\text { offers }\end{array}$ \\
\hline
\end{tabular}

Source: Author's aggregation based on Tomaro, 2016; Sviokla, 2016; Arp, 2015; Muehlhausen, 2013; Rappa, 
As the table clearly shows, there is no unique naming of the models and there are overlaps between the models, and providers of multiple services can be assigned in parallel to different models. Based on alternating strategies, environments, customers and market competition sometimes the business models change during a company's evolution. For this reason, it is impossible to define exactly which business model is the right one to be adopted and used by Smart Service providers. It is important to select the one that is best suited to it business and which helps to create, deliver and capture value. At the end a company needs to have a clear view on the three pillars pictured in figure 4.
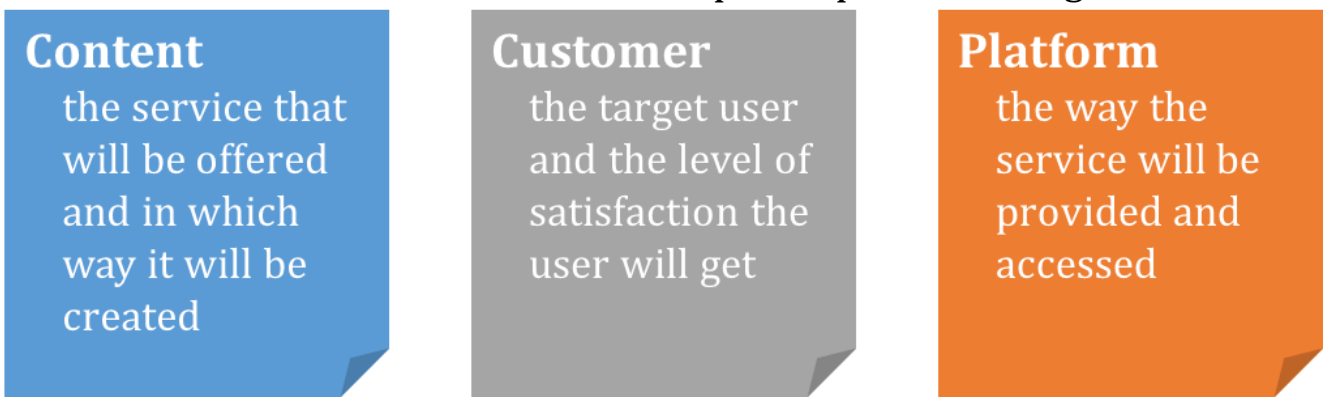

Figure 4. Three Pillars of a Business Model

Source: Author's design based on Rossides, 2014.

But not only he right selection of the business model matters, there are some more points to be considered. In figure 5 the author highlighted the major steps which need to be done when transforming towards Smart Services and selecting a supporting business model based on the attained understanding of the topic.

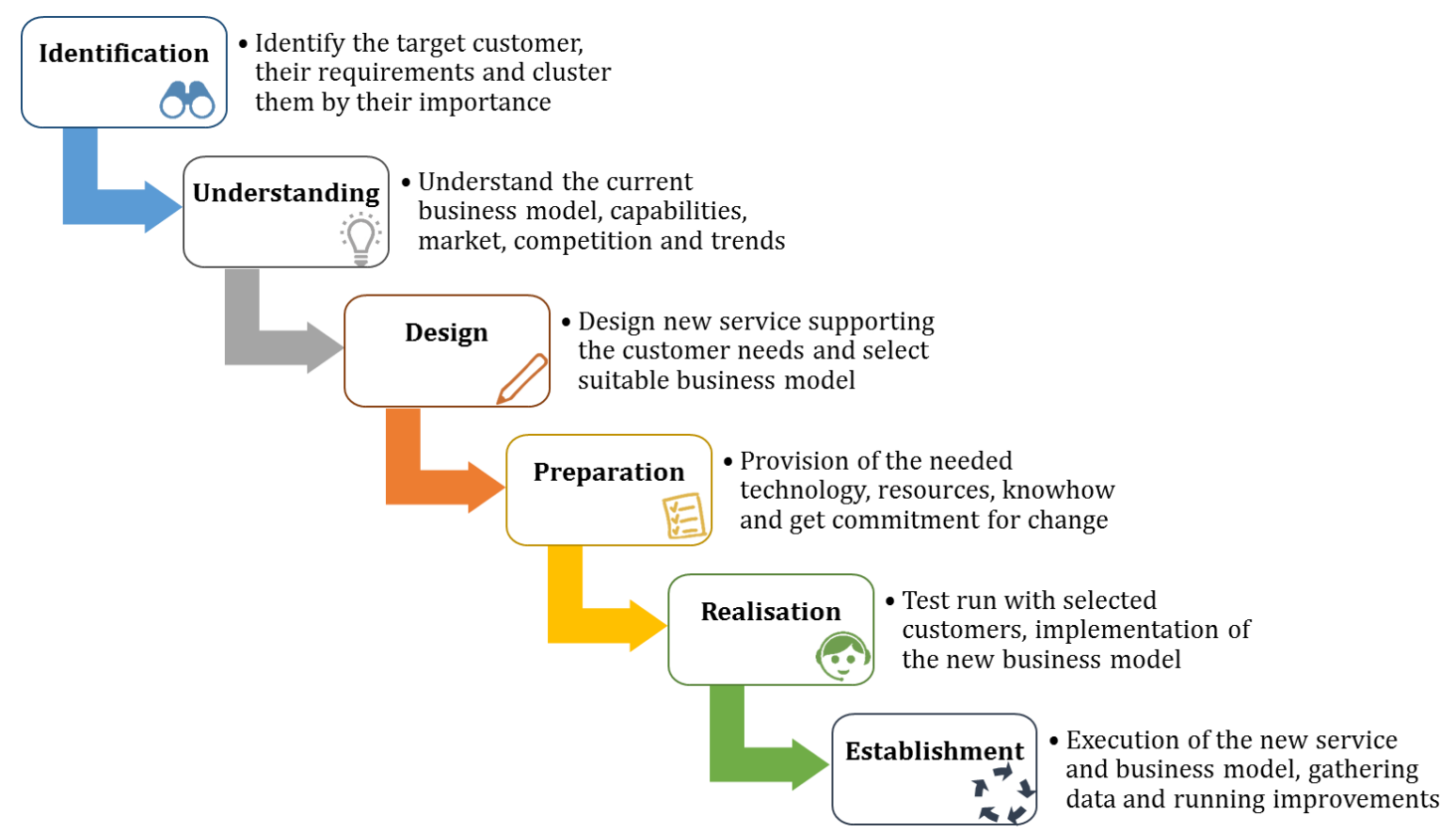

Figure 5. Major steps for establishing Smart Services with a supporting business model

Source: Author's design.

In the customer-centred approach it has to start with the customer and his requirement. When a company has identified that, the second logical step is the review of the own capabilities and the market situation. After an understanding has been achieved, it is about 
the mapping of the demand to the solution. Before the change towards this new defined service can starts it is indispensable to have the needed resources, technology and knowledge for the realisation. It is also important to get the commitment for the change and new approach from all involved parties otherwise it can cause problems and defence. Second to the last the new service and business model should be tested before carry out the change and go productive.

\section{Conclusion}

The findings illustrate that Smart Services are highly depending on digitalization, new technologies and data and it is important to acknowledge that they are not just an add on to existing products easy to realize. The identified challenges and opportunities shows that is complex and there is a lot of potential within the establishment of Smart Services but therefore paradigmatic changes are required in the way of cooperating, managing and consuming services. For straightforward and visionary companies the fourth industrial revolution offers a lot of possibilities and the leaders on the market have already shown what can be achieved when utilizing the new technologies. In addition it will show up in the next years which influence the governmental and industrial initiatives will have to establish supporting standards and regulation.

The major results of this research are based on an exploratory literature review, synthesized information from selected publications and pinpointed correlation. The author expects that this paper will increase the understanding of Smart Services, the adjacencies and encourage further research in this young and interesting topic and to arouse the interest of managers to use surpluses of Smart Services for their companies and customers.

The twenty first century has begun under the auspices of innovations and transformations, all those things that were seen as science fiction about 10 years ago are mostly science facts today and this development will continue and the evolution cycles get faster. A research about valuable and successful Smart Services is still needed, especially because the economical value might be not seen or recognized by the first day of its implementation and the high efforts for the preparation. Therefore, the next steps might be the verification of the findings through an expert survey and the collection of best practices to development a set of metrics for measuring the values provided by Smart Services.

\section{References}

Aghaei, S., Nematbakhsh, M.A., Farsani, H.K. (2012). Evolution of the World Wide Web:From Web 1.0 to Web 4.0. International Journal of Web \& Semantic Technology (IJWesT), 3 (1), 1-10. doi: 10.5121/ijwest.2012.3101.

Allmendinger, G. and Lombreglia, R. (2005). Four Strategies for the Age of Smart Services, Harvard Business Review. Retrieved from https://hbr.org/2005/10/four-strategiesfor-the-age-of-smart-services.

Arp, L. (2015, December 11). Do you know these popular online business models? Retrieved from http://sunriseprowebsites.com/know-popular-online-business -models.

Bley, S., Dr. Kilger, C., \& Prof. Dr. Vogel, J. (2016). Industrie 4.0 - das unbekannte Wesen?. Ernst \& Young GmbH. Retrieved from http://www.ey.com/Publication/ 
vwLUAssets/EY-industrie-4-0-das-unbekannte-wesen/\$FILE/EY-industrie-4-0-dasunbekannte-wesen.pdf.

BMBF - Federal Ministry of Education and Research. (2014). The new High-Tech Strategy Innovations for Germany. Retrieved from https://www.bmbf.de/pub /HTS_Broschuere_eng.pdf

BMWi. (2016). Industrie 4.0: The Digitisation of the Economy. Retrieved January 4, 2017, PICBE|799 from http://www.bmwi.de/Redaktion/EN/Artikel/Industry/industrie-4-0-thedigitisation-of-the-economy.html

Bosch Software Innovations. (2012, March). InnovatelT - Enabling Business Success in a Connected World. Retrieved from https://www.bosch-si.com/media/ bosch_software_innovations/documents/publication/german_1/2012_4/2012-01innovateit-kundenmagazin.pdf

Brynjolfsson, E., and McAfee, A. (2014). The second machine age: work, progress, and prosperity in a time of brilliant technologies. New York: W.W. Norton \& Company.

Cronin, M.J. (2010). Smart products, smarter services: strategies for embedded control. New York: Cambridge University Press.

Davies, R. (2015). Briefing - Industry 4.0 Digitalisation for productivity and growth. EPRS / European Parliamentary Research Service. Retrieved from http://www. europarl.europa.eu/RegData/etudes/BRIE/2015/568337/EPRS_BRI(2015)568337_ EN.pdf.

Eurodata. (2015). Whitepaper Smart Services und intelligente Vernetzung machen neue Geschäftsmodelle möglich. Retrieved from http://whitepaper.silicon.de/ resource/9157.

Financial Times Lexicon. (January 5, 2017). Business model. Retrieved from http://lexicon.ft.com/Term?term=business-model.

Gartner. (January 4, 2017). Digitalization. Retrieved from http://www.gartner.com /it-glossary/digitalization.

Goodreads. (January 7, 2017). A quote by Louis Pasteur. Retrieved from http://www.goodreads.com/quotes/9178-chance-favors-the-prepared-mind.

Hermann, S. (2016, October 20). Was sind Smart Services?. Smart Urban Services Project (SUS). Retrieved from http://www.servlab.eu/?p=1333.

IDC. (2015). Daten - Volumen der weltweit generierten Daten bis 2020 | Statistik. Retrieved from https://de.statista.com/statistik/daten/studie/267974/umfrage/prognosezum-weltweit-generierten-datenvolumeniiconsortium.org.

Kagermann, H. and Lukas, W.D. (2011, April 01). Industrie 4.0: Mit dem Internet der Dinge auf dem Weg zur 4. industriellen Revolution. Retrieved from http://www.vdinachrichten.com/Technik-Gesellschaft/Industrie-40-Mit-Internet-Dinge-Weg-4industriellen-Revolution.

Kagermann, H., Riemensperger, F., Hoke, D., Schuh, G., Scheer, A.-W., Spath, D., Leukert, B., Wahlster, W., Rohleder, B. and Schweer, D. (2015). Smart Service Welt. Umsetzungsempfehlungen für das Zukunftsprojekt Internetbasierte Dienste für die Wirtschaft (Abschlussbericht). Retrieved from http://www.acatech.de/ fileadmin/user_upload/Baumstruktur_nach_Website/Acatech/root/de/Projekte/La ufende_Projekte/Smart_Service_Welt/Smart_Service_Welt_2015/BerichtSmartServic eWelt2015_DE_KURZ.pdf. 
KPMG. (2016). Zeit zum mutigen Handeln. Frankfurt am Main. Retrieved from http://hub.klardenker.kpmg.de/zeit-zum-mutigen-handeln.

Marquardt, K., Olaru, M. and Ceausu, I. (2017). Study on the Development of Quality Measurements Models for Steering Business Services in Relation to Customer Satisfaction. Amfiteatru Economic, 19(44), 95-109.

Morgan, J. (2016, August 23). A Simple Explanation Of 'The Internet Of Things'. Retrieved PICBE | 800 from http://www.forbes.com/sites/jacobmorgan/2014/05/13/ simple-explanation-internet-things-that-anyone-can-understand.

Muehlhausen, J. (2013, July 02). Internet Business Models. Retrieved from http://businessmodelinstitute.com/internet-business-models.

Nations, D. (2016, May 13). What In the World Is 'Web 3.0' and Is It Even Here Yet?. Retrieved from https://www.lifewire.com/what-is-web-3-0-3486623.

O'Halloran, D. and Kvochko, E. (2015). Industrial Internet of Things: Unleashing the Potential of Connected Products and Services. World Economic Forum. Retrieved from http://www3.weforum.org/docs/WEFUSA_IndustrialInternet_Report 2015.pdf.

Ovans, A. (2015, January 26). What Is a Business Model?. Retrieved from https://hbr.org/2015/01/what-is-a-business-model.

Plattner, H. (2016, November 22). Big Data. Retrieved from http://www. enzyklopaedie-der-wirtschaftsinformatik.de/lexikon/daten-wissen/

Datenmanagement/Datenmanagement--Konzepte-des/Big-Data.

Porter, M.E. (1985). Competitive advantage: creating and sustaining superior performance. New York: Free Press.

PWC. (2016). Industry 4.0: Building the digital enterprise. Retrieved from https://www.pwc.com/gx/en/industries/industries-4.0/landing-page/ industry-4.0-building-your-digital-enterprise-april-2016.pdf.

Rappa, M. (2010). Business Models on the Web. Retrieved from http://digitalenterprise.org/models/models.html.

Rijsdijk, S. A., and Hultink, E. J. (2009). How today's consumers perceive tomorrow's smart products. Journal of Product Innovation Management, 26(1), 24-42.

Robben, X. (2015). Michael Porter's Value Chain: Increase value and beat the competition. Retrieved from https://books.google.de/books?i THd7CgAAQBAJ d=.

Rossides, N. (2014, March 04). Digital Business Models. Retrieved from https://www.digital-mr.com/blog/view/digital-business-models.

Schibrowski, E. (2008). Web 3.0: das Ende von Google. Retrieved from http://www.inf.unikonstanz.de/dbis/teaching/ws0708/web/essays/paper_schibrowski.pdf.

Steimel, B. (2016, November 25). Smart Services: Neue Geschäftsmodelle im Internet der Dinge. Retrieved from http://www.smarter-service.com/2016/11/25/ smart-services-neue-geschaeftsmodelle-im-internet-der-dinge.

Steimel, B. (2015). Einstieg in die Smart Service Welt / Neue Wertschöpfungspotentiale durch digitale Dienstleistungen. Retrieved from http://de.slideshare.net/ Bernhardsteimel/aufbruch-in-die-smart-service-welt.

Sviokla, J. (2016, December 08). Four Business Models for the Digital Age. Retrieved from http://www.strategy-business.com/blog/Four-Business-Models-for-the-Digital-Age.

Syska, A., and Liévre, P. (2016). Illusion 4.0 Deutschlands naiver Traum von der smarten Fabrik. Herrieden: CETPM Publishing. 
Tomaro, N. (2016, November 23). 9 Proven Business Models to Consider for Your Startup. Retrieved from http://www.huffingtonpost.com/nina-tomaro/9-proven-businessmodels-_b_7949932.html.

Töytäri, P. , Turunen, T., Klein, M., Eloranta, V., Biehl, S., Rajala, R. (2017). Overcoming Institutional and Capability Barriers to Smart Services. Retrieved from http://scholarspace.manoa.hawaii.edu/bitstream/10125/41351/1/paper0202.pdf.

Tydecks, W. (2013). Krise 2009, Ursachen und weitere Aussichten. Retrieved from http://www.tydecks.info/online/math_multi_krise2009.html.

UN DESA (2017). Weltbevölkerung - Anzahl der Einwohner auf der Welt 2015. Cited after de.statista.com. Retrieved from https://de.statista.com/statistik/daten/ studie/1716/umfrage/entwicklung-der-weltbevoelkerung.

Wahlster, W. (2008, August 12). Was ist der Unterschied zwischen Internet der Dienste... ?. Retrieved from https://www.youtube.com/watch?v=5hataOUdw9g.

Wee, D., Kelly, R., Cattel, J., and Breunig, M. (2016). Industry 4.0 after the initial hype where manufacturers are finding value and how they can best capture it. McKinsey \& Company. Retrieved from https://www.mckinsey.de/files/mckinsey_industry _40_2016.pdf.

Wee, D., Kelly, R., Cattel, J. Breunig, M. (2015). Industry 4.0 - how to navigate digitization of the manufacturing sector. McKinsey \& Company. Retrieved from https://www.mckinsey.de/files/mck_industry_40_report.pdf. 